\title{
Occupational exposure level of pig facility workers to chemical and biological pollutants
}

\author{
Anna Chmielowiec-Korzeniowska ${ }^{1, D}$, Leszek Tymczyna ${ }^{1, F}$, Magdalena Pyrz ${ }^{1, A}$, Beata Trawińska ${ }^{1, E}$, \\ Karol Abramczyk ${ }^{2, B}$, Magdalena Dobrowolska ${ }^{1, C}$ \\ 1 University of Life Sciences, Lublin, Poland \\ ${ }^{2}$ Institute of Soil Science and Plant Cultivation - State Research Institute, Puławy, Poland \\ A - Research concept and design, B - Collection and/or assembly of data, C - Data analysis and interpretation, \\ $D$ - Writing the article, E - Critical revision of the article, F- Final approval of article
}

\begin{abstract}
Chmielowiec-Korzeniowska A, Tymczyna L, Pyrz M, Trawińska B, Abramczyk K, Dobrowolska M. Occupational exposure level of pig facility workers to chemical and biological pollutants. Ann Agric Environ Med. 2018; 25(2): 262-267. doi: 10.26444/aaem/78479
\end{abstract}

\begin{abstract}
Objective. The aim of the study was to assess the impact of a fattening season on the level of airborne chemical and microbial pollutants in the pig fattening house.

Materials and method. Evaluation of the air composition as well as the microbiological air quality were made during 2 series, i.e. in the summer and winter period of fattening. Airborne gaseous pollutants were analyzed by gas (organic compounds) and liquid (inorganic compounds) chromatography methods. Air microbial contamination was determined in compliance with the Polish Standard PN-EN 13098:2007.

Results. The air/gas composition in the pig unit showed that irrespective of the fattening season, the level of determined pollutants - especially ammonia, volatile organic compounds (VOCs), including methanethiol and total dust - could have an adverse effect on the health of swine facility workers. The investigated pig building was found to be a source of chemical pollutants as well as biological agents. The total bacterial count in $1 \mathrm{~m}^{3}$ of air was $3.6 \times 10^{6}$ and $4.6 \times 10^{6} \mathrm{cfu}$, during the winter and summer periods of fattening, respectively. Gram-positive cocci predominated in both seasons. In the winter, fungi of the Trichoderma genus were represented equally often. In the summer period, up to $90 \%$ of the isolated fungus was Aspergillus spp.

Conclusions. Workers engaged in swine rearing and production are occupationally exposed not only to a high concentration of microbial contamination, but also to irritating and odorogenous volatile compounds. Thus, activities directed at the promotion of health prevention strategies, as well as effective guidelines for safe and hygienic animal housing, should be implemented.
\end{abstract}

\section{Key words}

environmental exposure, airborne contaminant, pig facility

\section{INTRODUCTION}

Indoor air in an animal building is contaminated with the products of decaying organic matter, i.e. alcohols, aldehydes, amines, organic chlorine compounds, and those emerging during sulphur amino acid metabolic processes in the animal gastrointestinal tract - sulfides and thiols $[1,2]$. Common components of the breeding environment are microbial pollutants, such as bacteria, fungi, viruses and their metabolites. The pollutants accumulated in confined animal buildings can pose serious health hazard to workers [3].

Most of the determined volatile organics (VOCs) are generated during the fermentation of fresh or stored animal manure and decomposing spoiled feed. The air contaminated with volatile chemicals produced at the breakdown of organic matter of animal origin can have toxic, irritating and even carcinogenic effects. These substances are irritants for the mucous membrane of the eyes, nose, throat and skin [4]. Schiffman et al. [4] report that these pollutants stimulate sensory nerves and cause neurochemical changes and, in turn, affect health. Long-term exposure to VOCs contributes

Address for correspondence: Anna Chmielowiec-Korzeniowska, University of Life Sciences in Lublin, ul. Akademicka 13, 20-950 Lublin, Poland

e-mail: anna.korzeniowska@up.lublin.pl

Received: 22.05.2017; accepted: 10.10.2017; first published: 06.11.2017 to compromised immune function in humans and leads to numerous diseases $[5,6,7,8,9,10,11]$. The symptoms, such as irritation of the eyes, nose and lips, headache, diarrhea, hoarseness, lip ulceration, cough, chest tightness, palpitation, shortness of breath, stress, drowsiness and mood disturbances, are symptoms commonly reported by residents living near swine farms [4]. Symptom intensity is dependent on air pollution concentration [12]. Irritation produced by volatile organic substances can also induce respiratory diseases/asthma [4], especially when VOC concentration in the air exceeds $2.5 \mathrm{mg} / \mathrm{m}^{3}$ [12]. It should also be borne in mind that pig facility workers are exposed to the influence of a whole complex of airborne factors. Here, besides the chemical factors, biological factors and organic dust (which is their main transmitter) occur in high intensity. According to the Regulation on Hazardous Biological Agents, implemented by European Council Directive 2000/54/EC, farmers are classified into the groups occupationally-exposed to biological agents at their workplace.

Air microflora composition depends primarily on the health status of the managed animals, hygiene conditions, quality of feedstuff and bedding. Nehme et al. [13] applied the methods of molecular technology and reported that the major source of microbial contamination of pig unit air is swine manure. In the pig house bioaerosol, fermenting bacteria were isolated which are characteristic for the anaerobic 
environment of the gastrointestinal system, including Grampositive bacteria from the genus Eubacterium, Clostridium, Bacillus-Lactobacillus-Streptococcus and Bacteroides, with the Clostridium bacteria group dominating. Studies by Predicala et al. [14] found that Gram-positive bacteria identified in swine building air were dominated by the genus Staphylococcus, Bacillus, Listeria, Enterococcus, Nocardia and Lactobacillus, whereas Gram-negative bacteria were mainly represented by Pseudomonas genus bacteria. According to Zucker and Müller [15], Gram-negative bacteria constituting the pig unit bioaerosol belonged to the family Enterobacteriaceae (71.2\%), Pseudomonadaceae (22.7\%) and Neisseriacceae (6.1\%) most frequently. Among them, Escherichia coli, Enterobacter agglomerans and Acinetobacter baumannii were most abundant. Most of bacteria were saprophytes, although some of them can be pathogenic or conditionally pathogenic.

The presence of moulds inside swine housing units is also considered a key biological risk factor. Pig farmers make up a group associated with heavy occupational exposure to inhalable mould spores. Adverse human health effects of fungi from the genus Aspergillus, Penicillum, Fusarium, Stachybotris or Trichoderma are generally known.

The environment of the animal facility favours rapid microbial multiplication and development, especially when appropriate sanitary and hygiene conditions are not maintained [16]. The most harmful biological agents present in the organic dust from hay, grain, animal skin and hair, are bacteria and fungi of animal and plant origin, together with the substances produced by them with allergenic and immunotoxic properties [17]. They can induce asthma, allergic rhinitis, extrinsic allergic alveolitis (EAA), chronic bronchitis, mucous membrane irritation, and other communicable diseases including zoonoses [18].

When inhaled, the bioaerosol with organic compounds derived from microorganisms (endotoxins, peptidoglycans, glucans and mycotoxins) induces an allergy-like effect on the pulmonary immune system, the so-called immunotoxic reaction. As a consequence, a fairly common disease known as toxic syndrome of organic dust (ODTS) (previously called mycotoxicosis) occurs [18].

The emission of hazardous agents associated with intensive pig farming poses a considerable health risk for workers engaged in livestock rearing and breeding. The problem pertains to a vast group of people, and data from the Central Statistical Office in Poland indicate that nearly 300,000 farms deal with pig production with private farms accounting for $99.8 \%$. Notably, most of farms are not supervised or controlled by the National Labour Inspectorate; consequently, no monitoring of the exposure levels of pig workers on swine farms is performed.

The objective of the presented study was to evaluate the effect of the fattening season on the airborne chemical and microbial contamination level in a pig fattening unit.

\section{MATERIALS AND METHOD}

The study was conducted on a private swine farm, average 105 LU. The animals were housed in 3 separate pig buildings: 1) with 2 boar stalls; 2 ) with a farrowing and rearing unit; 3 ) finishing unit - the fattening house. Air pollution monitoring was carried out in 2 chambers of the fattening unit.
The study included 2 full fattening cycles conducted in the summer and winter periods. The study commenced in January (winter period of fattening) and August (summer period of fattening) after the growing pigs of $25 \pm 2 \mathrm{~kg}$ body weight were introduced to the fattening facility. The studies lasted for the subsequent 4 months, until $112 \pm 4 \mathrm{~kg}$ body weight of pigs was acieved. The animals were managed in a straw-bedded deep litter which was removed once after each production cycle. Throughout the study period, the average animal number was 100 units/chamber and stocking density $0.8 \mathrm{~m}^{2} /$ unit. The ventilation system in the finishing unit was based on natural-mechanical ventilation with a thermal sensor. Fans automatically switched on when the indoor temperature rose to $18^{\circ} \mathrm{C}$. At low temperatures, the air exchange was accomplished only naturally.

In each chamber, 2 stationary sampling points were established. A total of 40 air samples were collected (20 in the summer and 20 in the winter period of fattening). Samples were always taken at the same time, 08:00, at the height of ca. $1.5 \mathrm{~m}$ above the floor, i.e. the workers' breathing zone. At the same time, the concentration of total dust in the swine fattening facility was measured, likewise, the relative humidity and temperature of the air and air movement were controlled.

Airborne gaseous organic pollutants were analyzed by the gas chromatography method. The air samples $\left(2-3 \mathrm{dm}^{3}\right)$ were collected using an electrical pump into Tedlar bags (Sensdidyne, Inc., Clearwater, USA). Organic substances present in the air samples were concentrated and then desorbed with a kit for thermal desorption (TDV Model 890, Dynatherm, Analytical Instruments, Inc., Oxford, USA), and for the chromatography system (HP 5890 series II, Hewlett Packard, Santa Clara, USA) equipped with a selective flame photometric detector (FPD) combined with S-filter of $393 \mathrm{~nm}$ wavelength.

Determination of inorganic compounds in the air samples, collected in bubblers, was performed with an ion chromatography system, using a liquid chromatograph connected with an analytical column IC-PAK Anion HR (Waters Corp., Milord, USA) combined with a conductometric detector and UV.

Air microbial contamination was determined in compliance with the Polish Standard PN-EN 13098:2007 by an aspiration procedure using a GilAir 5 air sampling pump (Sensdidyne, Inc., Clearwater, USA). The equipment operated at an airflow of $4 \mathrm{dm}^{3} / \mathrm{min}$. The measuring set was calibrated before each sampling procedure. The total count of bacteria and microscopic fungi was determined by the dilution plate method with surface inoculation onto suitable agar growth media. As for the total bacterial count (TSA medium - tryptic soy agar with $5 \%$ sheep blood), incubation was 7 days at $37^{\circ} \mathrm{C}\left(1\right.$ day), 3 days at at $22^{\circ} \mathrm{C}$, and 3 days at $4^{\circ} \mathrm{C}$ [19]. Total fungal numbers were established through air samples inoculation onto MEA medium (malt extract agar) with chloramphenicol, and incubation for 7 days -4 days at $30^{\circ} \mathrm{C}$ and 3 days at $25^{\circ} \mathrm{C}$. After incubation, the grown microbe colonies were assayed, the number of morphological types determined, their concentration in $1 \mathrm{~m}^{3}$ of air estimated and expressed in colony forming units (CFU). Identification of recovered microorganisms was performed with the microscopic method (moulds) and on the basis of their metabolic properties (bacteria) and API tests (bioMerieux, Poland, Warsaw). 
Dust level in the air was measured by a gravimetric method, with the air samples drawn via an aspirator (224-PCEX8, SKC, Dorset, UK). Air temperature, humidity and air movement determination was performed using standard procedures a thermohygrometer (RT811E, Technik, Warsaw, Poland) and an anemometer (A-1200M1, OBRAiUP, Lodz, Poland).

The obtained research results were analyzed statistically. All the determination results were characterized with arithmetical mean $(M)$ and the range of the values determined (MIN - MAX). Analysis of the seasonal effect on concentration of the air pollutants determined was conducted using the non-parametric Wilcoxon test with statistical software Statistica v.9.1. (StatSoft Inc., Tulsa, USA).

\section{RESULTS}

Compared to the summer fattening period, in the winter period there was determined a lower temperature (on average $7.5^{\circ} \mathrm{C}$ ), but a higher relative moisture content (on average $19.9 \%$ ) and air movement (on average $0.1 \mathrm{~m} / \mathrm{s}$ ) (Tab. 1 ). Average concentration of total dust in the ambient air was higher in the summer period of fattening by $3.7 \mathrm{mg} / \mathrm{m}^{3}$. The differences were statistically insignificant $(\mathrm{P}>0.05)$.

Table 1. Thermal-humidity conditions of outdoor and indoor air and total dust concentration in fattening unit

\begin{tabular}{|c|c|c|c|c|}
\hline \multirow{2}{*}{ Parameter } & \multirow{2}{*}{ Unit } & Winter season & Summer season & \multirow{2}{*}{$p$-value } \\
\hline & & Mean (Min - Max) & Mean (Min - Max) & \\
\hline \multicolumn{5}{|l|}{ Outdoor air } \\
\hline Temperature & ${ }^{\circ} \mathrm{C}$ & $12.5(4.2-20.1)$ & $22.1(15.9-29.4)$ & 0.191 \\
\hline Humidity & $\%$ & $59.1(50.3-71.0)$ & $47.3(31.6-59.7)$ & 0.318 \\
\hline \multicolumn{5}{|l|}{ Indoor air } \\
\hline Temperature & ${ }^{\circ} \mathrm{C}$ & $14.3(11.3-17.5)$ & $21.8(14.9-29.1)$ & 0.168 \\
\hline Humidity & $\%$ & $73.2(63.0-81.0)$ & $69.7(55.6-83.5)$ & 0.738 \\
\hline Air movement & $\mathrm{m} / \mathrm{s}$ & $0.2(0.1-0.4)$ & $0.1(0.0-0.1)$ & 0.137 \\
\hline Air dustiness & $\mathrm{mg} / \mathrm{m}^{3}$ & $3.3(0.8-6.7)$ & $7.0(5.0-9.2)$ & 0.161 \\
\hline
\end{tabular}

Results of the chromatographic analysis demonstrated substantial fluctuations. Total concentration of gaseous organic pollutants was slightly higher during the lower temperature period ( $p>0.05$ ) (Tab. 2). Among the identified pollutants, aldehydes and alcohols showed the highest level. Low-rate winter ventilation contributed to the elevated concentration of xylene and trichloroethylene $(\mathrm{p}<0.05)$. The presence of pentanal and naphtalene $(\mathrm{p}<0.05)$ was recorded only in the summer. Statistical differences were not reported for gaseous inorganic air contaminants (Tab. 3) and only an average chloride content was significantly higher than in the winter season $(\mathrm{p}<0.05)$.

Airborne gaseous sulfur compounds in the finishing unit reached a several times higher concentration in the summer period of fattening (Tab. 4); however, the differences were statistically significant $(\mathrm{p}<0.05)$ only for dipropyl sulfide. In this group of pollutants, thiols were determined at a very high level. In the winter season, methanethiol concentration exceeded $55 \mathrm{mg} / \mathrm{m}^{3}$ in individual samples.

The microbiological studies carried out in both seasons did not show statistically significant differences in microbial concentration (Tab. 5); however, in the summer period, the air of the fattening unit contained more pollutants
Table 2. Concentration of gaseous organic compounds in fattening unit air in summer and winter season $\left[\mu \mathrm{g} / \mathrm{m}^{3}\right]$

\begin{tabular}{|c|c|c|c|}
\hline \multirow{2}{*}{ Compound } & Winter season & Summer season & \multirow{2}{*}{$p$-value } \\
\hline & Mean (Min - Max) & Mean (Min - Max) & \\
\hline Total & $\begin{array}{c}2515.40 \\
(895.40-6009.40)\end{array}$ & $\begin{array}{c}2355.37 \\
(1225.60-4435.00)\end{array}$ & 0.864 \\
\hline \multicolumn{4}{|l|}{ In that identified: } \\
\hline Methane & $52.01(2.48-178.41)$ & 40.12 (b.d. - 146.99) & 0.763 \\
\hline Ethanol & 5.13 (b.d.- 29.02) & 7.11 (b.d. - 42.68) & 0.822 \\
\hline 2-butanamine & 48.41 (b.d. - 142.65) & 0.91 (b.d. -5.45 ) & 0.137 \\
\hline Propanol & 0.25 (b.d. - 1.49) & 26.34 (b.d. - 137.10) & 0.297 \\
\hline Cyclobutanol & 3.33 (b.d. - 19.99) & 2.79 (b.d. - 14.01) & 0.897 \\
\hline 1-propanol & 43.65 (b.d. - 176.85) & 1.83 (b.d. - 10.97) & 0.218 \\
\hline 1-butanol & 20.69 (b.d. - 64.39) & 3.28 (b.d. - 19.70) & 0.171 \\
\hline 2-pentaamine & 5.37 (b.d. - 17.49) & $38.51(2.01-93.02)$ & 0.094 \\
\hline Pentanal & n.d. & 1.80 (b.d. -4.03 ) & $0.037^{*}$ \\
\hline 2-methylpentan & 1.83 (b.d. - 9.39) & 77.40 (b.d. - 227.15) & 0.135 \\
\hline 2-metlyl-1-propanol & 2.06 (b.d. - 9.77) & 32.56 (b.d. - 170.45) & 0.323 \\
\hline Benzene & 15.62 (b.d. - 36.01) & 7.14 (b.d. - 22.28) & 0.297 \\
\hline Trichloroethylene & 78.53 (b.d. - 306.79) & $15.31(6.36-24.03)$ & $0.047^{*}$ \\
\hline 1-pentanol & $17.92(3.23-27.27)$ & $52.00(7.44-93.30)$ & $0.045^{*}$ \\
\hline Indoles & 36.83 (b.d. - 113.15) & $22.05(12.44-40.80)$ & 0.481 \\
\hline Ethylbenzene & 12.67 (b.d. - 32.09) & $43.39(3.48-77.98)$ & 0.071 \\
\hline Xylenes & $31.81(13.17-53.68)$ & 10.77 (b.d. - 42.77) & $0.040^{*}$ \\
\hline Phenol & 12.07 (b.d. - 25.50) & 14.14 (b.d. - 68.01) & 0.866 \\
\hline 3-carene & 7.87 (b.d. - 22.87) & 3.67 (b.d. - 13.55) & 0.385 \\
\hline Naphtalene & b.d. & 4.78 (b.d. - 17.99) & $0.019^{*}$ \\
\hline Methylocyclo pentane & $13.20(0.81-54.16)$ & 4.47 (b.d. - 11.71) & 0.353 \\
\hline Toluene & 11.04 (b.d. - 23.05) & $10.76(4.56-25.33)$ & 0.950 \\
\hline Hexanal & $102.30(5.65-578.66)$ & $44.79(8.76-122.84)$ & 0.579 \\
\hline
\end{tabular}

Table 3. Concentration of gaseous inorganic contaminants in fattening unit air in summer and winter season $\left[\mathrm{mg} / \mathrm{m}^{3}\right]$

\begin{tabular}{lccc}
\hline \multirow{2}{*}{ Compound } & Winter season & Summer season & \multirow{2}{*}{$p$-value } \\
\cline { 2 - 3 } & Mean $($ Min - Max $)$ & Mean $($ Min - Max $)$ & \\
\hline Total & $18.47(16.30-23.30)$ & $19.35(8.40-32.50)$ & 0.825 \\
\hline Ammonia & $17.98(15.80-22.70)$ & $17.23(7.60-29.20)$ & 0.832 \\
\hline Nitrates & b.d. & $0.13($ b.d. -0.30$)$ & 0.082 \\
\hline Chlorides & $0.38(0.30-0.50)$ & $1.33(0.70-2.00)$ & $0.013^{*}$ \\
\hline Sulfates & $0.10(0.10-0.10)$ & $0.65(0.10-1.30)$ & 0.066 \\
\hline
\end{tabular}

b.d. - below limit of detection

* - statistically significant differences

of bacterial origin, compared to the winter season when contaminants of fungal origin prevailed $(p>0.05)$. As for bacterial air pollutants, in both measurement periods of fattening, Gram-positive cocci were most abundant and their percentage reached $82.7 \%$ in the winter (Fig. 1). Only in the period of low temperatures, Corynebacterium afermentans and Enterococcus faecalis were identified in the fattening house air (Tab. 6). Among the fungi recovered from the finishing unit, those from the Aspergillus genus were most common. In the winter, fungi of the Trichoderma genus were represented equally often. 
Table 4. Concentration of gaseous sulfur compounds in fattening unit air in summer and winter season $\left[\mu \mathrm{g} / \mathrm{m}^{3}\right]$

\begin{tabular}{|c|c|c|c|}
\hline \multirow{2}{*}{ Compound } & Winter season & Summer season & \multirow{2}{*}{$p$-value } \\
\hline & Mean (Min - Max) & Mean (Min - Max) & \\
\hline Total & $\begin{array}{c}9592.69 \\
(55.99-56020.80)\end{array}$ & $\begin{array}{c}1114.86 \\
(82.66-4327.37)\end{array}$ & 0.404 \\
\hline \multicolumn{4}{|l|}{ In that identified } \\
\hline Hydrogen sulfide & $5.66(1.17-10.43)$ & 8.62 (b.d. - 16.81) & 0.396 \\
\hline $\mathrm{SO}_{2}$ & 10.11 (b.d. - 46.96) & 20.96 (b.d. - 72.29) & 0.450 \\
\hline Methanethiol & $\begin{array}{c}9456.69 \\
\text { (b.d. }-55959.70)\end{array}$ & $\begin{array}{c}150.96 \\
(13.34-246.03)\end{array}$ & 0.363 \\
\hline Ethanethiol & 29.05 (b.d. - 137.16) & 13.24 (b.d. - 54.65) & 0.537 \\
\hline $\mathrm{CS}_{2}$ & 36.78 (b.d. - 220.65) & b.d. & 0.363 \\
\hline Butanethiol & b.d. & 9.62 (b.d. - 50.45) & 0.295 \\
\hline Ethyl methyl sulfide & 7.91 (b.d. - 32.36) & $\begin{array}{c}875.03(15.76- \\
4009.12)\end{array}$ & 0.231 \\
\hline Diethyl sulfide & 0.10 (b.d. -0.29 ) & $9.44(0.70-45.33)$ & 0.252 \\
\hline Methyl propyl sulfide & 0.66 (b.d. - 1.85) & $6.16(0.43-28.72)$ & 0.278 \\
\hline Dipropyl sulfide & 1.08 (b.d. - 3.63) & 13.22 (b.d. - 36.56) & $0.043^{*}$ \\
\hline $\cos$ & 0.53 (b.d. -2.07 ) & $26.05(1.62-81.59)$ & 0.113 \\
\hline Methyl sulfide & b.d. & 6.53 (b.d. - 39.19) & 0.363 \\
\hline Isopropanethiol & 34.36 (b.d. - 107.40) & b.d. & 0.175 \\
\hline
\end{tabular}

b.d. - below limit of detection

* - statistically significant differences

Table 5. Level of air microbial contaminants in fattening unit in summer and winter season $\left[\times 10^{5} \mathrm{cfu} / \mathrm{m}^{3}\right]$

\begin{tabular}{lccr}
\hline \multirow{2}{*}{ Parameter } & Winter season & Summer season & \\
\cline { 2 - 3 } & Mean $($ Min - Max $)$ & Mean $($ Min - Max $)$ & \\
\hline Total bacterial count & $36.44(19.37-51.51)$ & $46.67(33.27-72.73)$ & 0.219 \\
\hline Total fungal count & $0.22(0.12-0.34)$ & $0.17(0.08-0.26)$ & 0.405 \\
\hline
\end{tabular}

Table 6. Percentage distribution of microorganisms identified in fattening unit air in summer and winter season

\begin{tabular}{ll}
\hline Season & Genus/species \\
\hline Bacteria & \\
\hline $\begin{array}{l}\text { Winter } \\
\text { season }\end{array}$ & $\begin{array}{l}\text { Micrococcus spp. (32.03\%), Staphylococcus lentus (28.35\%) Enterococcus } \\
\text { (0.96\%), Rhodococcus sp. (0.94\%), Staphylococcus xylosus (0.39\%), } \\
\text { Corynebacterium afermentans (0.39\%), others }\end{array}$ \\
\hline & $\begin{array}{l}\text { Staphylococcus lentus (54.59\%), Acinetobacter spp. (12.29\%), } \\
\text { Summer } \\
\text { season }\end{array}$ \\
$\begin{array}{l}\text { Streptococcus spp. (3.83\%), Neisseria polysacharea (2.31\%), Rhodococcus } \\
\text { spp. (1.59\%), Micrococcus spp. (0.29\%), Staphylococcus xylosus (0.29\%), } \\
\text { Acinetobacter junii (0.22\%), Kocuria varians (0.07\%), others }\end{array}$ \\
\hline $\begin{array}{l}\text { Fungi } \\
\text { Winter } \\
\text { season }\end{array}$ & $\begin{array}{l}\text { Trichoderma spp. (31.25\%), Aspergillus spp. (25.0\%), Cladosporium spp. } \\
\text { (25.0\%) Penicillium spp. (12.5\%), others }\end{array}$ \\
\hline $\begin{array}{l}\text { Summer } \\
\text { season }\end{array}$ & $\begin{array}{l}\text { Aspergillus spp. (99.89\%), Fusarium spp. (0.04\%), Ulocladium spp. } \\
\text { (0.01\%), Penicillium spp. (0.01\%), Rhizopus spp. (0.01\%), Cladosporium } \\
\text { spp. (0.01\%), others }\end{array}$ \\
\hline
\end{tabular}


The period of higher temperatures was marked by a distinct increase in the concentration of sulfides and alcohols - compounds produced at degradation/fermentation of faeces. This was associated with high microbial activity in the analyzed environment. Besides, a high concentration of total dust was observed in the pig building, its concentration, especially in the summer, greatly exceeded the established hygiene limits $\left(4 \mathrm{mg} / \mathrm{m}^{3}\right)$ (Dz.U.2014.817).

The study results reported by Bottcher [24] confirm that organic dust originating predominantly from feed, faeces and animal skin is major factor of pollutant emission occurring in animal production buildings. Von Borell et al. [25] highlight that increasing air dust concentration contributes to an increased content of not only ammonia and odorogenous compounds, but also to the overall count of microorganisms released into the air.

The presented study shows a very low sanitary state of air in the analyzed pig facility. Total bacterial count in $1 \mathrm{~m}^{3}$ in air in the winter season was $3.6 \times 10^{6} \mathrm{cfu}$, whereas $4.6 \times 10^{6} \mathrm{cfu}$ in the summer. High air microbial contamination in pig units has also been reported in other countries $[5,26]$. The obtained values were many times higher than the occupational human health-oriented hygienic norms $\left(2.0 \times 10^{5} \mathrm{cfu} / \mathrm{m}^{3}\right)$ for this sector [27].

Despite a lack of established standards on the allowable levels of air biological contamination, there are guidelines developed by the Institute of Rural Health in Lublin, Poland, according to which the threshold limit value for the work environment contaminated with organic dust is $100 \times 10^{3} \mathrm{cfu} /$ $\mathrm{m}^{3}$ for total mesophilic bacteria count $-20 \times 10^{3} \mathrm{cfu} / \mathrm{m}^{3} \mathrm{Gram}-$ negative bacteria and $50 \times 10^{3} \mathrm{cfu} / \mathrm{m}^{3}$ for fungi. Exceeding the occupational exposure limit increases the risk for potential harmful effects in exposed workers.

Comparing the values of microbiological contaminants recorded in both seasons, it is evident that atmospheric air temperature did not affect them. However, the measurements made by Nehme et al. [13] indicated significant influence of a season on the level of microbial pollutants. In the winter, elevated microbial concentration resulted from a reduced ventilation rate in the pig house. The studies of Kim et al. [28] have also shown that air microorganism numbers are significantly affected by raised air relative humidity and increased air movement. It means that a appropriate ventilation system in swine housing facilities should be well designed and managed since it greatly influences bioaerosol concentration in the swine house.

The current study shows a relatively low species variation in air microflora composition. Similar to Changa et al. [29], Gram-positive bacteria from the Staphylococcus and Micrococcus genus had high percentage contribution to total air microorganisms. Bacteria from the Enterococcus, Rodococcus and rod-shaped Corynebacterium spp. were also identified.

Gram-negative bacteria content in the pig unit air varied widely and ranged from $7.7 \%-22 \%$ in the total pool of identified bacteria. Bacteria from the Acinetobacter and Pseudomonas alcaligens genus were most abundant among them. Faecal streptococci were recovered only in the winter season, on average at the $7.6 \times 10^{5} \mathrm{cfu} / \mathrm{m}^{3}$ level. According to the classification by Dutkiewicz et al. [30], these bacteria belong to Hazard Group 2 and can trigger allergic and immunotoxic reactions induced by inhaled bacterial endotoxin (LPS). The microbiological evaluation showed that airborne fungal concentration in the analyzed pig unit was similar to the levels determined by Adhikari et al. [31] but markedly lower than that reported by Radon et al. [9].

In the summer samples, Aspergillus spp. represented more than $99 \%$ of identified fungi. Other frequently identified fungi included Fusarium spp., Ulocladium spp., Penicillium spp., Rhizopus spp. and Cladosporium spp. During the winter fattening, only 4 genus were identified. In the summer season, the genus differentiation of isolated bacteria was also higher.

Chang et al. [29] reported that among the fungi identified in the air samples from the swine housing unit, those of the Cladosporium genus were most abundant and, as the authors stated, this species may account for over $90 \%$ of the isolated fungi in the spring months. However, Jahnz-Różyk [32] indicated that these fungi, beside those from the Alternaria, Penicillum and Aspergillus genus, are the most common cause of inhaled allergy. Importantly, moulds are a source of not only mycotoxins but also of other volatile organic compounds (aldehydes, ketones, etc.) producing poisoning with general symptoms, immunotoxic glucans (1.3-beta-D-glucans) and also large molecule glucose polymers constituting fungal cell walls. The particles are responsible for ODTS development and chronic bronchitis incidence. Exposure to fungal metabolites can have an immunosuppressive or irritating effect on the mucosa of the airways, leading to chronic inflammatory conditions of the airway.

\section{CONCLUSIONS}

Air sanitary state in the workplace has a direct effect on the health and mood of workers, and therefore constitutes a vital aspect of occupational safety. Workers engaged in swine rearing and production are occupationally exposed not only to high concentrations of microbial contamination, but also to irritating and odorogenous volatile compounds. Evaluation of the gaseous composition of air in the pig housing unit showed that, irrespective of the fattening season, the level of contaminants determined, especially ammonia, volatile gaseous organics VOCs (methanethiol) and total dust, could adversely affect the health of pig facility workers. Notably, the chemical pollutants detected in the analyzed building could act in concert with biological agents also present, and have a negative synergistic effect on workers' health. Regarding the protection of pig producers health and safety, it is necessary to emphasize the relationship between the contamination level of a working environment, and the health effects in exposed workers. Thus, activities directed at the promotion of health prevention strategies, as well as effective guidelines for safe and hygienic animal housing, should be implemented.

\section{REFERENCES}

1. Akdeniz N, Jacobsona LD, Hetchlera BP. Health risk assessment of occupational exposure to hazardous volatile organic compounds in swine gestation, farrowing and nursery barns. Environ Sci Processes Impacts. 2013; 15: 563-572.

2. Chmielowiec-Korzeniowska A. The concentration of volatile organic compounds (VOCs) in pig farm air. Ann Agric Environ Med. 2009; 16(2): 189-194.

3. Karwowska E. Microbiological air contamination in farming environment. Pol J Environ Stud. 2005; 14(4): 445-449. 
4. Schiffman SS, Williams CM. Science of odor as a potential health issue. J Environ Qual. 2005; 34: 129-138.

5. Banhazi TM, Rutley DL, Pitchford WS. Identification of risk factors for sub-optimal housing conditions in Australian piggeries: Part 4. Emission factors and study recommendations. J Agric Saf Health. 2008; 14(1): 53-69.

6. Charavaryamath Ch, Singh B. Pulmonary effects of exposure to pig barn air. J Occup Med Toxicol. 2006; 1: 1-10.

7. Kai P, Schäfer A. Identification of key odour components in pig house air using hyphenated gas chromatography olfactometry. Agric Engng Internat the CIGR Journal of Scientific Research and Development. Manuscript BC 04 006. Vol. VI. December. 2004

8. Lubiński W, Toczyska I, Chciałowski A, Płusa T. Influence of air pollution on pulmonary function In healthy young men from different regions of Poland Ann Agric Environ Med. 2005; 12: 1-4.

9. Radon K, Damser B, Iversen M, Monso E, Weber Ch, Hartung J, Donham KJ, Palmgren U, Nowak D. Air contaminants in different European farming evironments. Ann Agric Environ Med. 2002; 9: 41-48.

10. Rappert S, Müller R. Odor compounds in waste go emissions from agricultural operations and food industries. Waste Manag. 2005; 25 : 887-907.

11. Zhang G, Strfm JS, Li B, Rom HB, Morsing S, Dahl P, Wang C. Emission of Ammonia and other contaminant gases from naturally ventilated dairy cattle building. Biosyst Eng. 2005; 93(3): 355-364.

12. Nielsen GD, Larsen ST, Olsen O, Løvik M, Poulsen LK, Glue C, Wolkoff P. Do indoor chemicals promote development of airway allergy? Indoor Air. 2007; 17(3): 236-255.

13. Nehme B, Létournau V, Forster RJ, Veillette M, Duchaine C. Cultureindependent approach of the bacterial bioaerosol diversity in the standard swine confinement buildings, and assessment of the seasonal effect. Environ Microb. 2008; 10(3): 665-675.

14. Predicala BZ, Urban JE, Maghirang RG, Jerez SB, Goodband RD. Assessment of bioaerosols in swine barns by filtration and impaction. Curr Microbiol. 2002; 44(2): 136-40.

15. Zucker BA, Müller W. Species composition and sources of airborne gram-negative bacteria in animal houses. Proc. Xth Int. Con. Animal Hygiene, 2-6 July. Maastricht, The Netherlands. 2000.

16. Popescu S, Borda C, Diugan EA, Oros D. Microbial air contamination in indoor and outdoor environment of pig farms. Anim Sci Biotechn. 2014; 47(1): 182-187.

17. Buczyńska A, Szadkowska-Stańczyk I. Problemy higieny pracy i zagrożenia zdrowotne towarzyszące intensywnej produkcji trzody chlewnej. Med Pracy. 2010; 61(3): 323-331.
18. Dutkiewicz J, Cisak E, Sroka J, Wójcik-Fatla A. Zając W. Biological agents as occupational hazards - selected issues. Ann Agric Environ Med. 2011; 18(2): 286-293.

19. Dutkiewicz J. Exposure to dust-borne bacteria in agriculture. I. Environmental studies. Archiv Environ Health. 1978; 33: 250-259.

20. Feron VJ, Cassee FR, Vliet PW, van Zorge JA. International issues on human health effects of exposure to chemical mixtures. Environ Health Perspect. 2002; 110(6): 893-899.

21. Blanes-Vidal V, Hansen MN, Pedersen S, Rom HB. Emissions of ammonia, methane and nitrous oxide from pig houses and slurry: Effects of rooting material, animal activity and ventilation flow. Agric Ecosyst Environ. 2008; 124: 237-244.

22. Staicu E, Drăghici M, Bădic L, Ivanciu C, Mitrănescu E. Research on monitoring microclimate chemical factors and their influence on the welfare of intensive swine rearing system. Bull UASVM Vet. Med. 2008; 65(1): 222-224.

23. Rzeźnik, W, Mielcarek P. Evaluation of the selected microclimate parameters in a fully-slatted piggery. Agric Engn. 2015; 19 (2): 75-87.

24. Bottcher RW. An environmental nuisance: odor concentrated and transported by dust. Chem Senses. 2001; 26: 327-331.

25. von Borell E, Özpinar A, Eslinger KM. Acute and prolonged effects of ammonia on hematological varibles,stress responses, performance and behavior of nursery pigs. J Swine Health Prod. 2007; 15(3): 137-145.

26. Eduard W, Douwes J, Omenaas E, Heederik D. Do farming exposures cause or prevent asthma? Results from a study of adult Norwegian farmers. Thorax. 2004; 59: 381-386.

27. Krzysztofik B. Mikrobiologia powietrza. Wyd. Politechniki Warszawskiej, Warszawa, 1992.

28. Kim KY, Ko HJ, Kim YS, Kim CN. Assessment of Korean farmer's exposure level to dust in pig buldings. Ann Agric Environ Med. 2008; 15: 51-58.

29. Chang CW, Chung H, Huang CF, Su HJJ. Exposure of workers to airborne microorganisms in open-air swine houses. Appl Environ Microbiol. 2001; 67: 155-161.

30. Dutkiewicz J, Śpiewak R, Jabłoński L, Szymańska J. Biologiczne czynniki zagrożenia zawodowego. Klasyfikacja, narażone grupy zawodowe, pomiary, profilaktyka. Ad Punctum, Lublin, 2007.

31. Adhikari A, Reponen T, Lee SA, Grinshpun SA. Assessment of human exposure to airborne fungi in agricultural confinements: personal inhalable sampling versus stationary sampling. Ann Agric Environ Med. 2004; 11: 269-277.

32. Jahnz-Różyk K. Wprowadzenie do alergii na antygeny grzybów pleśniowych. Pol Merk Lek. 2008; 24: 7-10. 